\title{
DETERMINATION OF FEED QUALITY PARAMETERS OF LEAVES AND STEMS OF DIFFERENT ALFALFA GENOTYPES
}

\author{
Onur Okumus ${ }^{1}$, Beyza Ciftci ${ }^{1}$, Sati Uzun ${ }^{1 *}$, Mahmut Kaplan ${ }^{1}$ \\ ${ }^{1}$ Erciyes University, Faculty of Agriculture, Department of Field Crops, Kayseri, Turkey
}

Current Trends in

Natural Sciences

\begin{abstract}
This research was carried out to determine feed quality parameters of leaves and stems of different alfalfa genotypes. A total of 12 alfalfa genotypes was used as the plant material for the study. Alfalfa plants were harvested at the flowering stage. The plants were dried at $70^{\circ} \mathrm{C}$ and grinded in a hand-mill with $1 \mathrm{~mm}$ sieve for chemical analysis. In leaf, the acid detergent fiber $(A D F)$ content of genotypes varied between $21.62-27.40 \%$, the neutral detergent fiber (NDF) content between 33.98 - 39.95\%, and crude protein content between $24.68-28.45 \%$, whereas in stem ADF content of genotypes varied between $50.99-57.72 \%$, NDF content between $66.96-76.79 \%$, crude protein content between $8.46-11.00 \%$. The RFV ranged from 159.18 to $197.27 \%$ and 53.22 to $67.06 \%$ for leaf and stem respectively. The leaf to stem ratio of genotypes ranged from 0.72 to 1.60. Considering current results from different genotypes, genotype has a high effect on feed quality. In addition, the rate of leaf to stems is also effective on feed quality. While the protein ratio of the leaves was higher than the stems, the ADF and NDF contents were found to be lower than the stems. So, in the selection of alfalfa genotypes, attention should be paid to the leaf to stem ratio as well as the yield.
\end{abstract}

Keywords: Alfalfa, chemical composition, crude protein, leaf to stem ratio.

\section{INTRODUCTION}

Alfalfa (Medicago sativa L.) is one of the most important perennial forage crops in the world and it is used primarily as hay, pasture, or green forage for a wide variety of livestock (Avc1 et al., 2018). It can be grown a wide range of climatic and soil conditions. Alfalfa has the high yield potential and feeding values. Alfalfa has high protein content (15-22\%) as well as vitamins and minerals (Kumar, 2011). Besides forage yield and quality, alfalfa provides remarkable agronomic and environmental advantages in terms of soil fertility, protection against soil erosion, rate of nitrogen fixation per year (Annicchiarico, 2015).

High feed quality is very important in animal husbandry and "high quality" varieties need to be developed. The leaf to stem ratio is used as a synthetic positive indicator of feed quality because the leaves have higher digestibility than the stems (Annicchiarico, 2015; Grev et al., 2020). At an average harvest maturity, leaves are rich in protein and low in cell wall concentration, therefore, it has a high nutritional value and is highly digestible (Jung et al., 1997; Markovic et al., 2012; Grev et al., 2020). The stems, on the other hand, have low digestibility properties because of high concentrations of cell wall polysaccharides and lignin (Grev et al., 2020). Also, as maturity progresses, stems they somehow lose their digestibility than leaves (Sheaffer et al., 2000). Many 
factors are used to estimate feed quality, such as crude protein ratio, ADF, NDF contents and total digestible nutrient (Avc1 et al., 2018). Our objective was to determine some quality parameters of leaves and stems of different alfalfa genotypes at the flowering stage stages.

\section{MATERIALS AND METHODS}

This study was conducted from 2020, at the Experimental Field of Erciyes University, Kayseri, Turkey. Experimental soils were classified as sandy-loam. Soils had low lime and salt content, poor in organic matter and were slightly alkaline. The long-term average temperature (1980-2019) was $10.7^{\circ} \mathrm{C}$. The long-term average annual rainfall was $345.06 \mathrm{~mm}$. Total rainfall during the growing season in March, April, May, and June of 2020 was $190.6 \mathrm{~mm}$. The average temperatures during these months were $7,10.2,15.5$ and $19.3{ }^{\circ} \mathrm{C}$ respectively.

Local populations collected from different locations of Kayseri provience were planted in the field at $1 \mathrm{~m}$ intra and inter row spacing in 2019. Experimental area was irrigated with drip irrigation during the growing season. At the flowering stage (more than 60-70\% of stem had flowers), selected 12 different single plant were harvested on 16 June 2020. After counted stem number, samples were divided by hand into stem and leaf fractions, weighed and determined leaf to stem ratio. Leaf and samples taken from each plant were oven-dried at $70{ }^{\circ} \mathrm{C}$ and ground to pass through a $1 \mathrm{~mm}$ screen for chemical analysis. Crude protein, acid detergent fiber (ADF) and neutral detergent fiber (NDF) contents of samples were determined by using near infrared reflectance spectroscopy (NIRS, Foss 6500) with software program coded IC-0904FE. The relative feed value was calculated according to the formula reported by Schroeder (2004).

\section{RESULTS AND DISCUSSIONS}

There were differences in number of stem, leaf and stem green herbage yield, leaf to stem ratio, crude protein, ADF and NDF contents of genotypes (Table 1 and 2). Number of stem of genotypes ranged from 24 to 74 . The average stem number was 48 stems. Leaf and stem green herbage yield varied between 100-650 g/plant, and 115-905 g/plant respectively (Table 1). Leaf-to-stem ratio ranged from 0.72 to 1.60 . The average leaf to stem ratio of genotypes was 1.06 . Leaf to stem ratio above average was obtained from GnyA, GnyC, GnyD, GnyE, Gny6, Gny75, and Gny114. Avc1 et al. (2018) stated that leaf to stem ratio of some alfalfa cultivars varied between 0.71-1.08 and Tucak et al. (2014) found leaf to stem ratio of 22 alfalfa populations/cultivars between 0.880-1.011, which were similar with our data. Rotili et al. (1999) stated that the quality of alfalfa is mainly influenced by leaf to stem ratio and the plant with the leaf to stem ratio of 0.85-1.0 is defined as an ideal plant in terms of quality.

Crude protein content of alfalfa genotypes ranged from $24.68 \%$ to $28.45 \%$ for leaf and from $8.46 \%$ to $11 \%$ for stem (Table 2). Mean crude protein content of genotypes was $26.66 \%$ and $9.92 \%$ for leaf and stem respectively. GnyC, Gny6, Gny29, Gny55 and Gny75 had above average crude protein for both leaf and stem. Leaf crude protein content was higher than stem, which was in line with the findings of Sheaffer et al. (2000) and Markovic et al. (2012). In the previous researches, crude protein content for alfalfa was found as 28.3 and $9.3 \%$ for leaf and stem by Jung et al. (1997); 11.84 $-26.12 \%$ and $0.40-8.04 \%$ for leaf and stem respectively by Nan et al. (2019). Sheaffer et al. (2000) determined the protein content in leaves and stems of alfalfa as $28.4-30.4 \%$ and $11.3-11.5 \%$ in the early flowering harvest regimes and $26.4-27.8 \%$ and $9.6-10.2 \%$ in the late flowering harvest regimes in three locations. 


\section{Current Trends in Natural Sciences}

Vol. 10, Issue 20, pp. 118-121, 2021

https://doi.org/10.47068/ctns.2021.v10i20.016

Current Trends in Natural Sciences (on-line)

Table 1. Number of stem, leaf and stem green herbage yield (g/plant) and leaf to stem ratio of some alfalfa genotypes

\begin{tabular}{|l|l|l|l|l|}
\hline \multirow{2}{*}{ Genotypes } & \multirow{2}{*}{ Number of Stem } & \multicolumn{2}{|c}{ Green Herbage Yield } & \multirow{2}{*}{ Leaf to Stem Ratio } \\
\cline { 3 - 4 } & & \multicolumn{2}{|c|}{ Leaf } & \multicolumn{2}{c|}{ Stem } & \\
\hline GnyA & 50 & 340 & 295 & 1.15 \\
\hline GnyC & 60 & 495 & 310 & 1.60 \\
\hline GnyC1 & 24 & 170 & 215 & 0.79 \\
\hline GnyD & 44 & 345 & 320 & 1.08 \\
\hline GnyE & 41 & 360 & 230 & 1.57 \\
\hline Gny6 & 48 & 260 & 245 & 1.06 \\
\hline Gny29 & 70 & 650 & 905 & 0.72 \\
\hline Gny55 & 38 & 495 & 550 & 0.90 \\
\hline Gny75 & 74 & 330 & 305 & 1.08 \\
\hline Gny76 & 25 & 100 & 115 & 0.87 \\
\hline Gny114 & 47 & 200 & 180 & 1.11 \\
\hline Gny125 & 51 & 295 & 390 & 0.76 \\
\hline Mean & $\mathbf{4 8}$ & $\mathbf{3 3 7}$ & $\mathbf{3 3 8}$ & $\mathbf{1 . 0 6}$ \\
\hline
\end{tabular}

Table 2. Crude protein (\%), acid detergent fiber (ADF, \%), neutral detergent fiber (NDF, \%), and relative feed value (RFV, \%) in leaves and stems of some alfalfa genotypes at the flowering stage

\begin{tabular}{|l|l|l|l|l|l|l|l|l|}
\hline \multirow{2}{*}{ Genotypes } & \multicolumn{2}{|c}{ Crude protein } & \multicolumn{2}{c}{ ADF } & \multicolumn{2}{c|}{ NDF } & \multicolumn{2}{c|}{ RFV } \\
\cline { 2 - 9 } & Leaf & \multicolumn{1}{|c|}{ Stem } & \multicolumn{1}{|c|}{ Leaf } & Stem & Leaf & Stem & Leaf & Stem \\
\hline GnyA & 26.1 & 10.30 & 22.96 & 55.92 & 36.19 & 69.59 & 182.54 & 60.61 \\
\hline GnyC & 26.9 & 10.34 & 23.56 & 53.62 & 37.47 & 70.98 & 175.14 & 61.77 \\
\hline GnyC1 & 26.58 & 9.08 & 21.99 & 56.21 & 35.68 & 75.27 & 187.11 & 55.75 \\
\hline GnyD & 25.91 & 8.46 & 24.65 & 57.72 & 37.09 & 76.79 & 174.80 & 53.22 \\
\hline GnyE & 25.1 & 10.65 & 27.40 & 51.78 & 39.08 & 67.37 & 160.80 & 67.06 \\
\hline Gny6 & 27.31 & 9.86 & 23.77 & 56.84 & 38.38 & 72.93 & 170.59 & 56.92 \\
\hline Gny29 & 27.24 & 11.00 & 22.28 & 50.99 & 35.01 & 68.71 & 190.10 & 66.58 \\
\hline Gny55 & 27.82 & 9.73 & 22.10 & 55.43 & 36.97 & 74.46 & 180.37 & 57.12 \\
\hline Gny75 & 28.45 & 10.86 & 21.62 & 52.86 & 33.98 & 68.38 & 197.27 & 64.92 \\
\hline Gny76 & 25.81 & 9.55 & 22.79 & 56.41 & 34.70 & 72.10 & 190.73 & 58.00 \\
\hline Gny114 & 24.68 & 9.58 & 26.87 & 52.81 & 39.72 & 66.96 & 159.18 & 66.35 \\
\hline Gny125 & 28.00 & 9.65 & 23.67 & 54.57 & 39.95 & 70.13 & 164.07 & 61.53 \\
\hline Mean & $\mathbf{2 6 . 6 6}$ & $\mathbf{9 . 9 2}$ & $\mathbf{2 3 . 6 4}$ & $\mathbf{5 4 . 6 0}$ & $\mathbf{3 7 . 0 2}$ & $\mathbf{7 1 . 1 4}$ & $\mathbf{1 7 7 . 7 2}$ & $\mathbf{6 0 . 8 2}$ \\
\hline
\end{tabular}

The ADF content of genotypes ranged from 21.62 to $27.40 \%$ and 50.99 to $57.72 \%$, for leaf and stem respectively, whereas NDF content ranged from 33.98 to $39.95 \%$ and 66.96 to 76.79 for leaf and stem respectively. On average, the ADF and NDF were 23.64 and $37.02 \%$ in leaf, and were 


\section{Current Trends in Natural Sciences}

Vol. 10, Issue 20, pp. 118-121, 2021

https://doi.org/10.47068/ctns.2021.v10i20.016

Current Trends in Natural Sciences (on-line)

54.60 and $71.14 \%$ in stem, respectively. Crude protein was greater in leaf than in stem, whereas ADF and NDF were lower in leaf than in stem. Similarly, Sheaffer et al. (2000) reported ADF and NDF concentrations as $17.1-18.6 \%$ and $20.5-22 \%$ for leaf and as 52.3-56 \% and 61.6-65.8\% for stem respectively.

The RFVs of genotypes ranged from 159.18 to $197.27 \%$ and 53.22 to $67.06 \%$ for leaf and stem respectively. According to alfalfa hay quality standards RFV $>151$ was classified in high-quality forages (Markovic et al., 2010). RFV in leaves of all genotypes were higher than this value and the RFV of leaves was greater than stems. Grev et al. (2020) reported that leaf fractions in alfalfa had higher forage nutritive value compared to stem fractions across all maturities.

\section{CONCLUSIONS}

There were differences in number of stem, leaf to stem ratio, and leaf and stem nutritional qualities of genotypes. Leaf-to-stem ratio ranged from 0.72 to 1.60 . Leaves accumulated high contents of CP. ADF and NDF were lower in leaves than in stems. And also leaves had higher RFV. Further examination of the cloned genotypes over multiple cuttings and years is necessary to fully understand their superior traits.

\section{REFERENCES}

Annicchiarico, P. (2015). Alfalfa forage yield and leaf/stem ratio: narrow-sense heritability, genetic correlation, and parent selection procedures. Euphytica, 205(2), 409-420.

Avci, M., Hatipoglu, R., Çinar, S., Kiliçalp, N. (2018). Assessment of yield and quality characteristics of alfalfa (Medicago sativa L.) cultivars with different fall dormancy rating. Legume Research-An International Journal, 41(3), 369-373.

Grev, A. M., Wells, M. S., Catalano, D. N., Martinson, K. L., Jungers, J. M., Sheaffer, C. C. (2020). Stem and leaf forage nutritive value and morphology of reduced lignin alfalfa. Agronomy Journal, 112(1), 406-417.

Jung, H. G., Sheaffer, C. C., Barnes, D. K., Halgerson, J. L. (1997). Forage quality variation in the US alfalfa core collection. Crop Science, 37(4), 1361-1366.

Kumar, S., 2011. Biotechnological advancements in alfalfa improvement. Journal of applied genetics, 52(2), 111-124.

Marković, J. P., Štrbanović, R. T., Terzić, D. V., Djokić, D. J., Simić, A. S., Vrvić, M. M., Živković, S. P. (2012). Changes in lignin structure with maturation of alfalfa leaf and stem in relation to ruminants nutrition. African Journal of Agricultural Research, 7, 257-264.

Marković, J., Štrbanović, R., Terzić, D., Pojić, M., Vasić, T., \& Babić, S. (2010). Relative feed value oo alfalfa (Medicago sativa L.) and red clover (Trifolium pratense L.) at different stage of growth. Biotechnology in Animal Husbandry, 26, 469-474.

Nan, L., Nie, Z., Zollinger, R., Guo, Q. (2019). Evaluation of morphological and production characteristics and nutritive value of 47 lucerne cultivars/lines in temperate Australia. Plant Production Science, 22(4), 490-500.

Rotili, P., Gnocchi, G., Scotti, C., \& Zannone, L. (1999). Some aspects of breeding methodology in alfalfa. In Proc. of The Alfalfa Genome Conference, Madison, USA.

Schroeder, J. W. (2004). Forage nutrition for ruminants. North Dakota State University Extension Service, No: 1250.

Sheaffer, C. C., Cash, D., Ehlke, N. J., Henning, J. C., Jewett, J. G., Johnson, K. D., Peterson, M.A., Smith, M., Hansen, J.L., Viands, D. R. (1998). Entry X environment interactions for alfalfa forage quality. Agronomy Journal, 90(6), 774-780.

Sheaffer, C. C., Martin, N. P., Lamb, J. F., Cuomo, G. R., Jewett, J. G., Quering, S. R. (2000). Leaf and stem properties of alfalfa entries. Agronomy journal, 92(4), 733-739.

Tucak, M., Popovic, S., Cupic, T., Krizmanic, G., Spanic, V., Simic, B., Meglic, V. (2014). Agro-morphological and forage quality traits of selected alfalfa populations and their application in breeding. Turkish Journal of Field Crops, 19(1), 79-83. 